\title{
Implementation of Android-based Application for learning Legu Salai Dance
}

\author{
Jacquline Morlav S. Waworundeng ${ }^{1}$, Fergie Joanda Kaunang ${ }^{2}$, \\ Deddy Tampanguma ${ }^{3}$, Iksan $^{4}$ \\ 1,2,3,4 Fakultas Ilmu Komputer, Universitas Klabat \\ jacquline.morlav@unklab.ac.id
}

\begin{abstract}
The development of the technology has influenced the way of learning. Besides the conventional learning, the Android-based applications which run on smartphones potentially become complement for learning process. The implementation of Android application has developed in various fields including art and culture. This research mainly discusses about the implementation of the Legu Salai dance learning application, which is built based on Android and testing the functionality of the application. The purpose of making the application is to introduce the Legu Salai dance, to provide related information about the dance and as a learning tool of the dance movements. The research stage uses the Waterfall methods which is modeled by Unified Modeling Language. The application is built using the Java programming language, while the testing process uses the black box testing method. User who want to learn the Legu Salai dance can install the applications on Android smartphone and can accessed the available features. The application can display information about Legu Salai dance in the form of text, images, audio and video. The test results indicate that the application can function according to its design. This application can be an alternative medium to learn and introduce the Legu Salai dance as one of Indonesia's cultural wealth. For future development, the features of the application can be extended by adding the information about the variation and formation the Legu Salai dance and also provide the information about the traditional costume which is wear by the dancer.
\end{abstract}

Keywords: learning application, Android, dance, Legu Salai.

\section{INTRODUCTION}

Culture is a wealth that needs to be preserved. The Indonesian state has a complex cultural diversity with local wisdom that illustrates the habits practiced by the people. One type of dance that contains local wisdom is the Legu Salai dance. This dance is a celebration of the people of Sahu in Halmahera at the time of the rice harvest. According to the history of rice cultivation in Halmahera, it only began in the 16th century. The Legu Salai dance represents the excitement of the Sahu community during the rice harvest. In celebrating the rice harvest, the Legu Salai dance is not formal or sacred. However, in other contexts such as birthday gifts, welcoming the 
Sultan of Ternate and oversized guests, the Legu Salai dance became a formal dance (Pattiasina 2015).

\section{LITERATURE REVIEW}

Along with the development of technology, various media and applications have been used and developed to support the learning process. There are several references related to this research. In an article (Tomczak 2011) which discuss the use of interactive media such as computer programs or applications with the aim of helping the dance search process. Another article (Franza et al. 2016) discusses the application of Balinese dancing that uses Augmented Reality on Android aimed at preserving Balinese dancing with interactive learning features. Article (Agustina et al. 2015) suggests a puzzle game application on Android to educate users about traditional clothing from all over Indonesia. Reserach (Tirayoh et al. 2015) discussed about the application of traditional musical instruments, the Totobuang musical instrument, which can be played using between the layers of the hand on a smartphone that produces sounds from the instrument. A study (Khaeruzzaman 2014) discussed about Android based client server which provide information about Indonesian traditional dances.

From the previous references discussed that media or Android-based applications have become a means to support Indonesian culture and can help users to obtain local culture. Researchers see an opportunity to create an Android-based application that can be accessed via an Android-based smartphone for learning Legu Salai dance, with the aim that through this application can help introduce or learn about the Legu Salai dance culture in Halmahera Regency.

\section{METHODS}

Legu Salai dance application based on Android, designed using the software engineering methodology (Pressman and Maxim 2015) which emphasizes the exact completion time. This method fits the Waterfall model, which prioritizes each stage to fit the evaluation so that it can proceed to the next stage according to the schedule. The software engineering methodology can provide a solution because it covers every aspect of software development starting from application requirements analysis, design, coding, testing and application maintenance.

Figure 1 shows the design of the research carried out in making the application. In the communication phase, researchers gather information to make a Legu Salai dance tutorial. In addition, researchers also collected references regarding Android-based learning applications. In the planning stage, researchers gather information about the software needed to build 
Android-based applications. The modeling stage is the stage of identifying the functionality and features of the application using the Unified Modeling Language (UML).

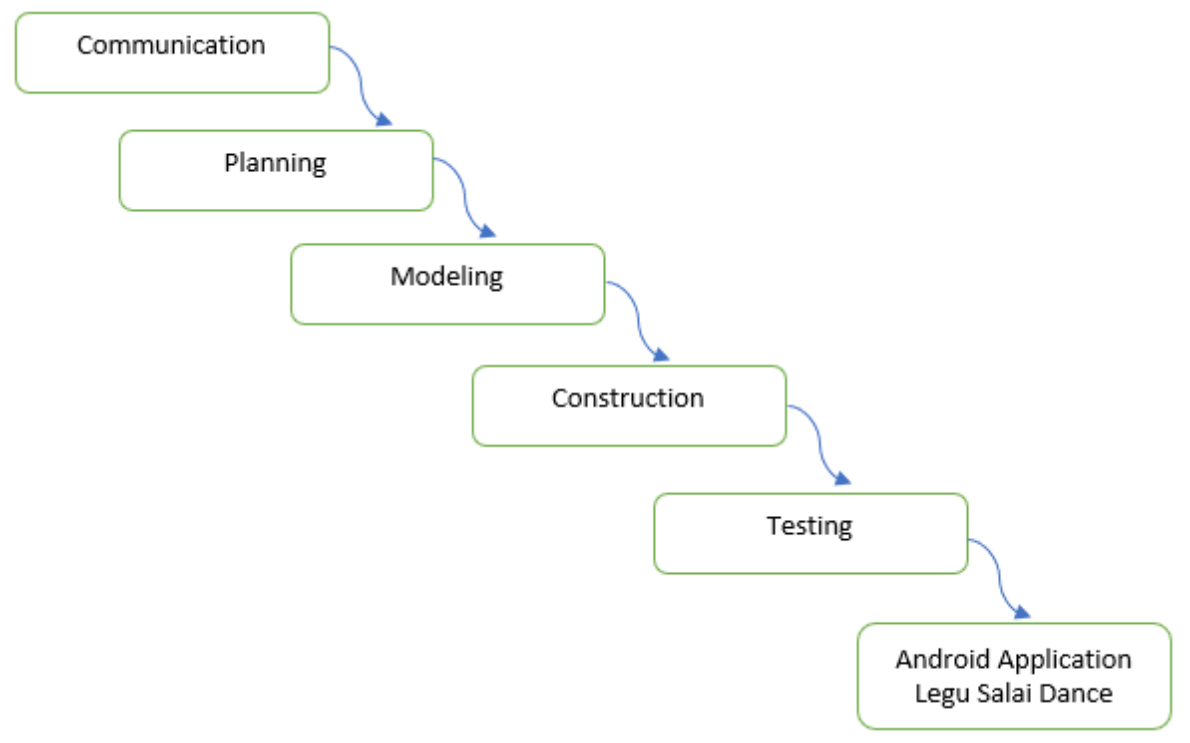

Figure 1. Research Method

Researchers have previously suggested the design of the Legu Salai dance application using UML consisting of use case diagrams, class diagrams, sequence diagrams and activity diagrams (Waworundeng 2018). After design with UML, researchers have also made an application interface design. The communication, planning and modeling phases have been discussed on the previous research. The next stage are construction and testing stages. The construction phase is the stage of making application code using the Java programming language. Testing phase is a stage to test whether the application can fulfill predetermined functions. Testing is done using the Black Box method. If all the necessary functions have been fulfilled, the application is ready to use and the last step is the submission of the application to the user.

The software used to build the Android application are the Java programming language, Java editor Eclipse Indigo, Notepad ++ as XML editor. To run the application, an Android-based smartphone is used.

\section{RESULTS}

Figure 2 (Waworundeng et al. 2018) shows the design of the application. The application provided five main menus in Indonesian language that can be accessed namely the dance (tarian) menu, the history (sejarah) menu, the help (bantuan) menu, the about (tentang) menu 
and the exit (keluar) menu. Users can install applications on Android-based smartphones and access the menus available in the application

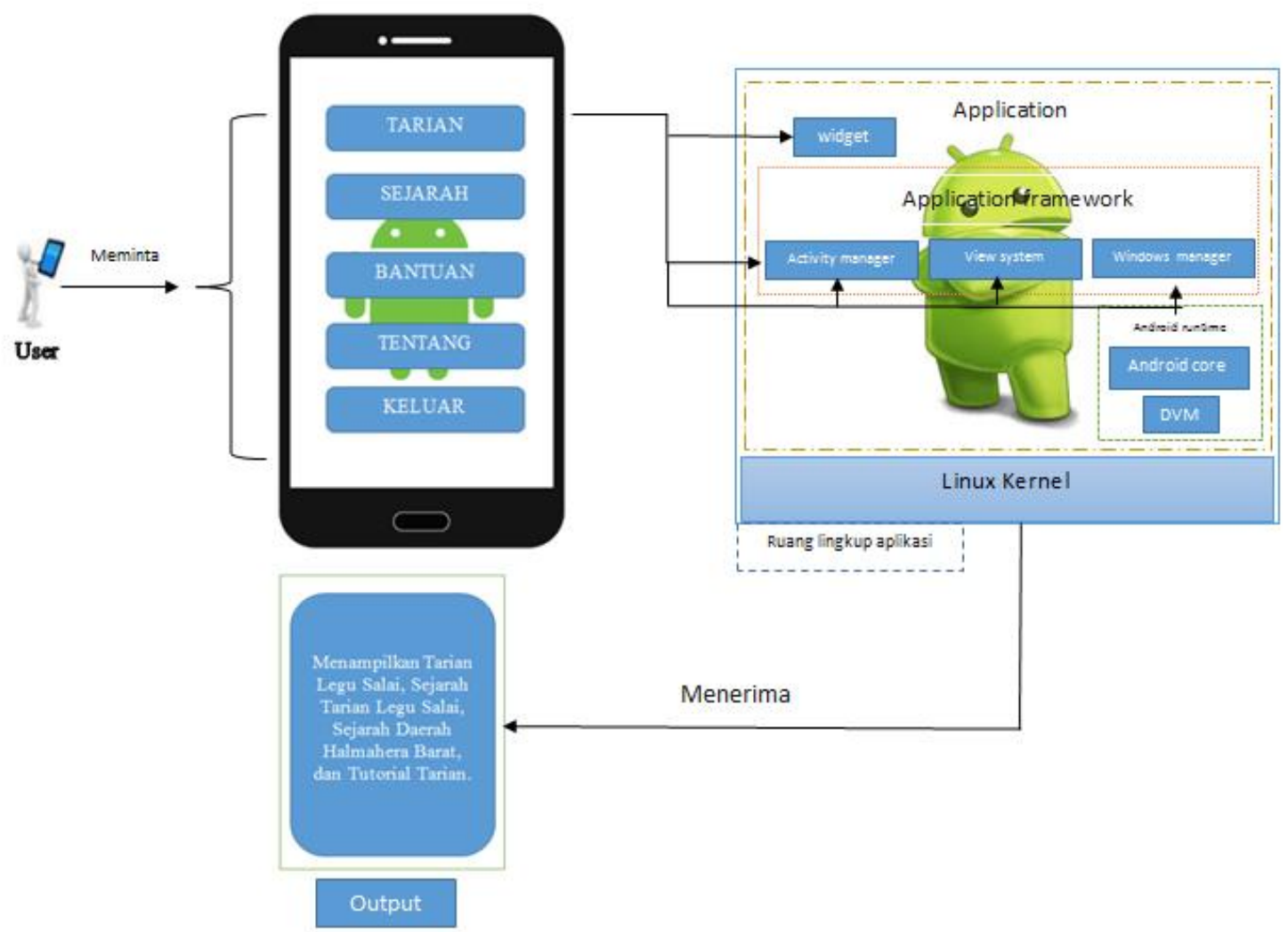

Figure 2. Design of Android application of Legu Salai Dance

The implementation of the main menu of the Legu Salai dance application is shown in Figure 3 which consists of five menus namely tarian, sejarah, bantuan, tentang, and keluar. The tarian menu provides information about the dance tutorial shown by images and texts. In addition, the dance menu can also play videos about the Legu Salai dance. The interface implementation of the dance sub-menu is shown in Figure 4. 


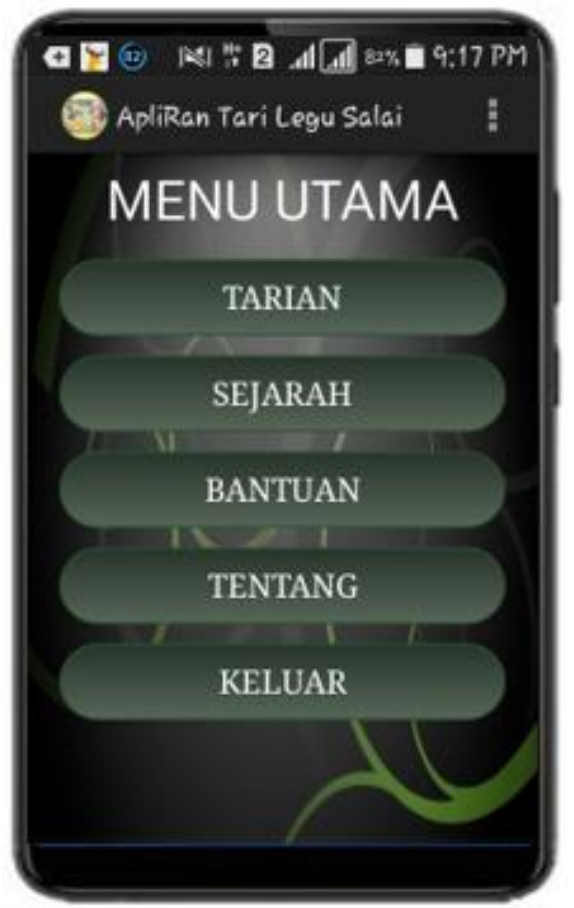

Figure 3. Main Menu of Application

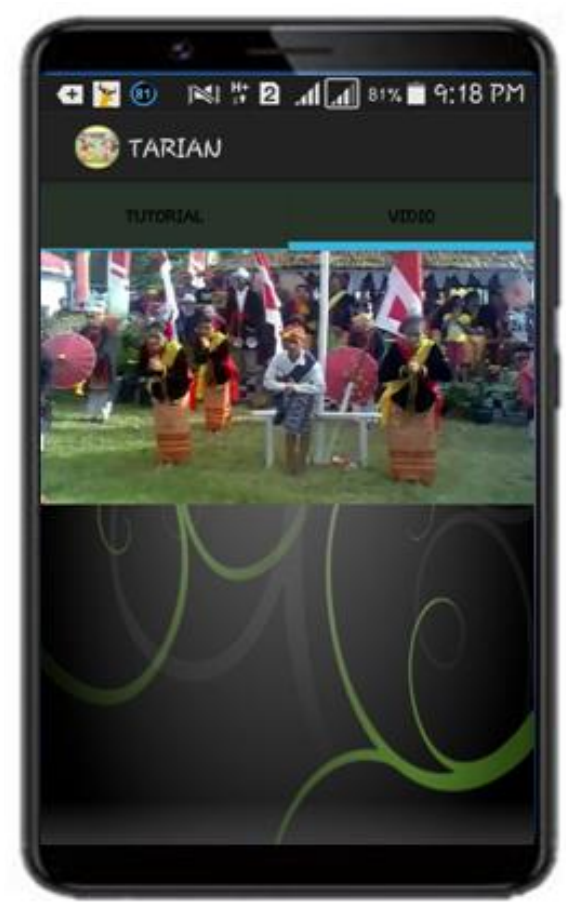

Figure 5. Menu Video

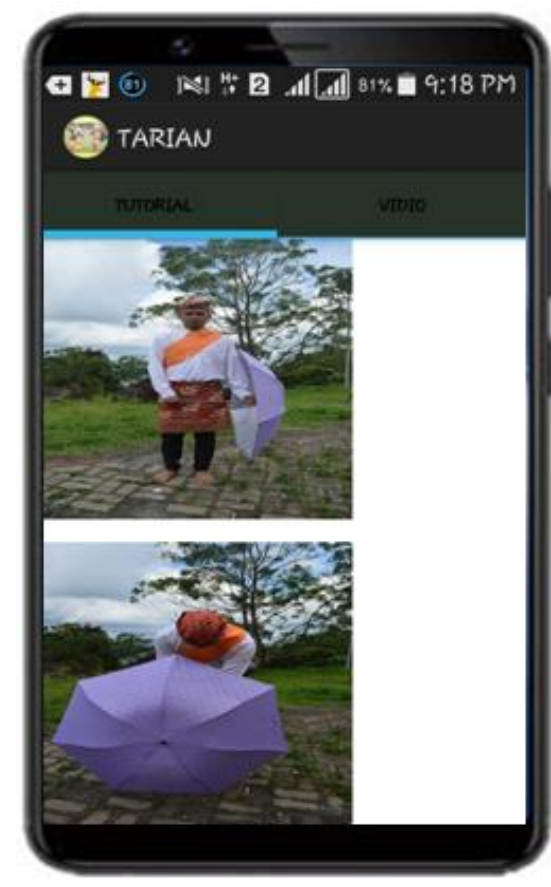

Figure 4. Main Dance Tutorial

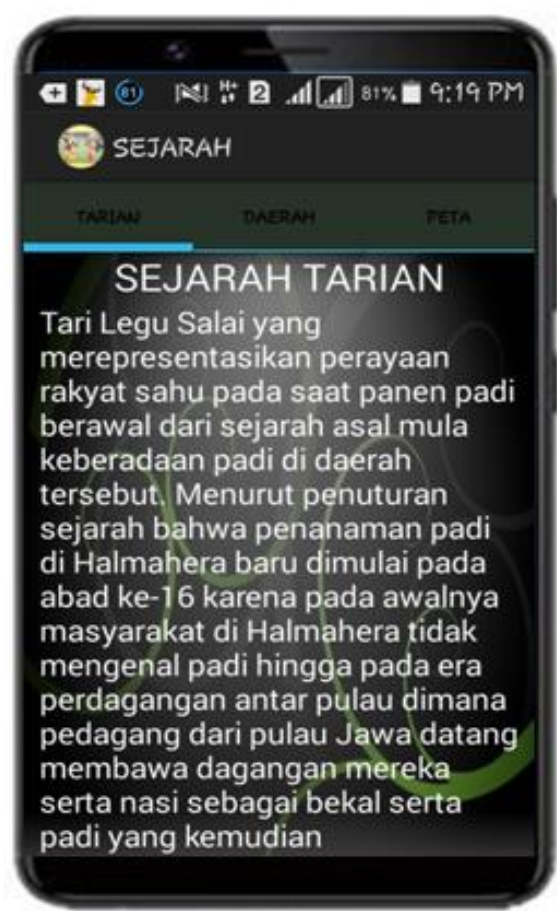

Figure 6. Menu Dance History 


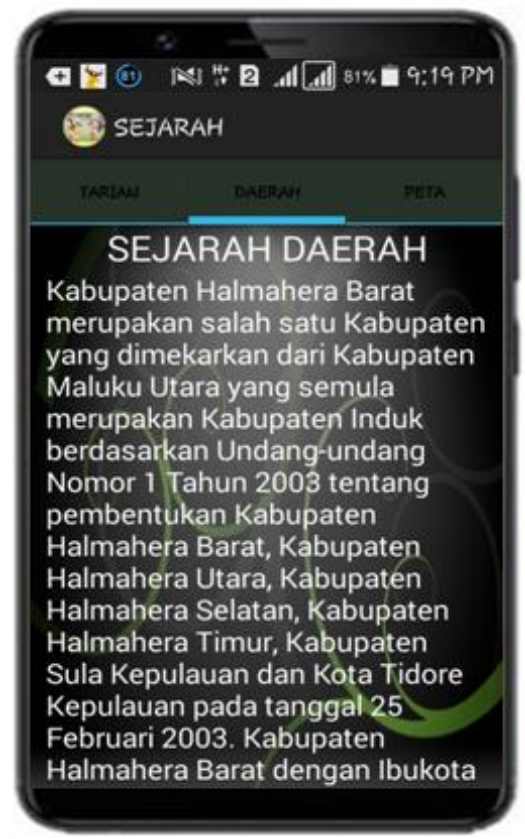

Figure 7. Menu of Halmahera History

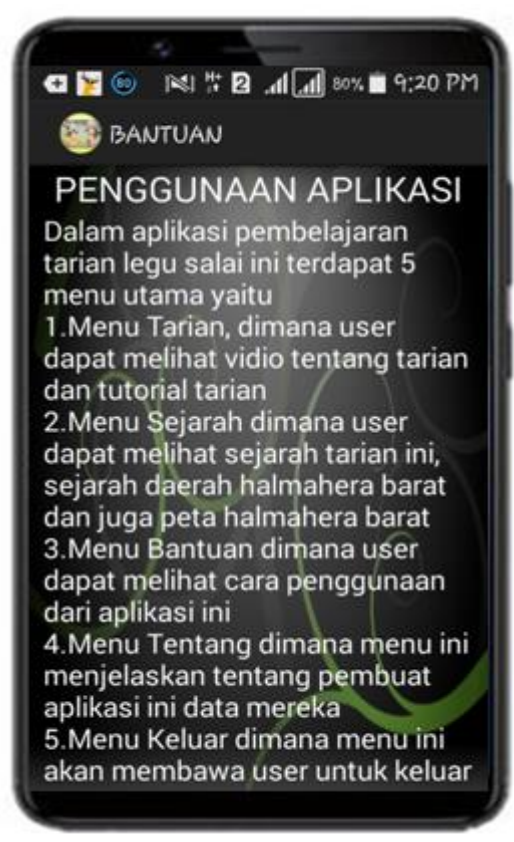

Figure 7. Menu of application

\section{Reporting Research Results}

Application testing is the stage to check if the application are functioning well according to the intended purpose or there are mall function. Tables 1 through 9 show the test results using the black box testing method. In general, black box testing is a test that observes and checks every function of a system or software.

Table 1. Testing the dance (tarian) menu access

\begin{tabular}{|c|c|}
\hline Input & Accessing the dance Menu on the application \\
\hline Process & $\begin{array}{c}\text { A database process that contains information about the } \\
\text { dance }\end{array}$ \\
\hline Expected Output & $\begin{array}{l}\text { Display two sub-menus namely dance tutorials and dance } \\
\text { videos }\end{array}$ \\
\hline Result & Success \\
\hline
\end{tabular}

Table 2. Testing dance tutorial (tutorial tarian) sub-menu access

\begin{tabular}{|c|c|}
\hline Input & \begin{tabular}{c} 
Accessing the dance tutorial sub-menu on the application \\
\hline Process
\end{tabular} \\
$\begin{array}{c}\text { Process database with text and image formats which } \\
\text { contain information about dance tutorials }\end{array}$ \\
\hline Expected Output & Displays text and images of dance tutorials \\
\hline Result & Success \\
\hline
\end{tabular}


Table 3. Testing the dance video (video tarian) sub-menu access

\begin{tabular}{|c|c|}
\hline Input & Access the dance video sub-menu on the application \\
\hline Process & Process database with video format \\
\hline Expected Output & Showing the dance videos \\
\hline Result & Success \\
\hline
\end{tabular}

Table 4. Testing history (sejarah)menu

\begin{tabular}{|c|c|}
\hline Input & Access the history menu on the application \\
\hline Process & $\begin{array}{l}\text { A database process that contains information about } \\
\text { history }\end{array}$ \\
\hline Expected Output & $\begin{array}{c}\text { Featuring two sub-menus namely dance history and } \\
\text { regional history }\end{array}$ \\
\hline Result & Success \\
\hline
\end{tabular}

Table 5. Testing dance history (sejarah tarian) sub-menu

\begin{tabular}{|c|c|}
\hline Input & Access the dance history sub-menu on the application \\
\hline Process & $\begin{array}{c}\text { A database process that contains information about dance } \\
\text { history }\end{array}$ \\
\hline Expected Output & Displays information about the history of dance \\
\hline Result & Success \\
\hline
\end{tabular}

Table 6. Testing the regional history (sejarah daerah)sub-menu

\begin{tabular}{|c|c|}
\hline Input & $\begin{array}{c}\text { Access the regional history sub-menu on the application } \\
\text { Process }\end{array}$ \\
$\begin{array}{c}\text { Database process that contains information about the } \\
\text { history of the area }\end{array}$ \\
\hline Expected Output & Displays information about the history of the area \\
\hline Results & Success \\
\hline
\end{tabular}

Table 7. Testing help (bantuan) menu

\begin{tabular}{|c|c|}
\hline Input & Access the help menu on the application \\
\hline Process & $\begin{array}{l}\text { A database process that contains information about using } \\
\text { the application }\end{array}$ \\
\hline Expected Output & Display the information about the application \\
\hline Result & Success \\
\hline
\end{tabular}

Table 8. Testing about (tentang) menu

\begin{tabular}{|c|c|}
\hline Input & Access the about menu \\
\hline Process & $\begin{array}{l}\text { Database process that contains information about the } \\
\text { menu }\end{array}$ \\
\hline Expected Output & Displays information about the application developer \\
\hline Result & Success \\
\hline
\end{tabular}


Tabel 9. Testin exit (keluar) menu

\begin{tabular}{|c|c|}
\hline Input & Access Exit Menu \\
\hline Process & Processed the Exit Menu \\
\hline Expected Output & User can Exit from Application \\
\hline Result & Success \\
\hline
\end{tabular}

From the tests conducted, it was founded that the functions that have been determined in the application design process can be achieved and successful in accordance with the objectives, so that the Legu Salai dance learning application is ready to install and use by the user.

\section{DISCUSSION}

This research mainly discussed about an application which has the basic and simple tutorial of how to learn a Legu Salai dance as one of traditional dance in Indonesia to preserve the culture. The application specifically provided the Legu Salai dance tutorial with text, images and video in Indonesian language. User who want to study the dance, could installed the application on their Android smartphone and access the menus. The application shows the text information, images and video but uncapable to assess the user movement when they tried to practice the dance. For future research, the tutorial and application could be developed through Augmented Reality with the function of assessing the movement. The application can be developed by adding variation and formation movement of Legu Salai dance and also provide information about the traditional costume of the dancer.

\section{Conclusion}

The conclusions obtained are as follows:

1. menus that can be accessed in this application consists of dance (tarian), history (sejarah), help (bantuan), about (tentang) and exit (keluar),

2. the application can display information of Legu Salai dance in the form of videos, dance tutorials, history of Legu Salai dances, regional history and map of the region,

3. data formats used in this application in the form of text, images and video,

4. application testing carried out by the black box testing method and the results is well function according to the design, 
5. the application can be installed and run on Android smartphones which can help user to learn the Legu Salai dance,

6. the application can be an alternative medium to learn and introduce the Legu Salai dance as one of Indonesia's cultural wealth.

\section{REFERENCES}

Pattiasina, J. 2015. Tari Legu Salai dari Ternate Maluku Utara, Kementerian Pendidikan dan Kebudayaan Balai Pelestarian Nilai Budaya Ambon.

Tomczak MA, K. 2011. Using Interactive Media in Dance Education. Journal of Dance Education, Vol. 11, 137-139. Retrieve from https://bit.ly/2IwXNb9

Franza, N.P.S., Oka Sudana, A.A.K., and Wibawa, K.S. 2016. Application of Basic Balinese Dance Using Augmented Reality on Android. Journal of Theoritical and Applied Information Technology. Vol. 90. No.1, 61-65. Retrieve from https://bit.ly/2Oq4qSd

Agustina, C., and Wahyudi, T. 2015. Aplikasi Game Pendidikan Berbasis Android untuk memperkenalkan pakaian adat Indonesia. Indonesian Journal on Software Enggineering Vol. 1, No. 1. Retrieve from https://bit.ly/2Oq6bPj

Tirayoh, A., Meddelu S., and Sahulata, R.A. 2015. Aplikasi Alat Musik Tradisional Totobuang Berbasis Android, Cogito Smart Journal, vol. 1, no 1, hal 68-77. Retrieve from https://bit.ly/2QpAUJz

Khaeruzzaman, Y. 2014. Aplikasi Informasi Pengetahuan Tari Tradisional Indonesia dan Modern menggunakan Client Server Berbasis Android. Inti Talafa: Jurnal Teknik Informatika, Vol 6, No. 2. Retrieve from https://tinyurl.com/yxgzh6yb

Waworundeng, J., Tampanguma, D., and Iksan. 2018. Desain Aplikasi Pembelajaran Tarian Legu

Salai Berbasis Android, Seminar Nasional Sistem Informasi dan Teknologi Informasi (Sensitek 2018), hal. 379-384, https://bit.ly/2xVcoci

Pressman R.S., and Maxim B.R. 2015, Software Engineering: A Practitioner's Approach, Ed. 8, McGraw Hill Education. 